\title{
Effect of sperm concentration during preincubation in a defined medium on fertilization in vitro of pig follicular oocytes
}

\author{
T. Nagai, K. Niwa and A. Iritani \\ Department of Animal Science, College of Agriculture, Kyoto University, Kyoto 606, Japan
}

\begin{abstract}
Summary. Pig follicular oocytes cultured in a defined medium for $28-29 \mathrm{~h}$ were inseminated in vitro by epididymal or ejaculated boar spermatozoa that were preincubated in a modified KRB solution at various sperm concentrations for $4 \mathrm{~h}$ at $37^{\circ} \mathrm{C}$. Sperm concentration at insemination was $2 \times 10^{6} \mathrm{cells} / \mathrm{ml}$. When epididymal spermatozoa were preincubated at concentrations of $4-16 \times 10^{8} \mathrm{cells} / \mathrm{ml}, 71-75^{\circ} \%$ of oocytes were penetrated. In contrast, preincubation at a low concentration $\left(0.8 \times 10^{8}\right.$ cells $/ \mathrm{ml}$ ) resulted in a low penetration rate $(11 \%)$. Epididymal spermatozoa preincubated at a concentration of $4 \times 10^{8} \mathrm{cells} / \mathrm{ml}$ could also penetrate denuded oocytes. None of the oocytes were penetrated by epididymal spermatozoa that were exposed to seminal plasma before preincubation or by ejaculated spermatozoa. After preincubation, whiplash motility was observed in the epididymal spermatozoa, but not in the ejaculated spermatozoa.
\end{abstract}

\section{Introduction}

Successful in-vitro fertilization of pig eggs was reported for epididymal and ejaculated spermatozoa when they were preincubated in female genital tracts (Iritani, Niwa \& Imai, 1978; Nagai, Niwa, Iritani \& Leidl, 1983), but, when spermatozoa were preincubated in a chemically defined medium, only 1 of 30 oocytes was penetrated by epididymal spermatozoa. Pavlok (1981) has reported that zona-free pig oocytes were penetrated by ejaculated spermatozoa when they were preincubated in vitro at a high concentration. The present experiment was to investigate fertilization in vitro of pig eggs by epididymal and ejaculated spermatozoa preincubated in vitro at various sperm concentrations.

\section{Materials and Methods}

\section{Culture of follicular oocytes}

Ovaries were removed from Landrace sows and gilts at a local slaughterhouse and returned to the laboratory in saline $(9 \mathrm{~g} \mathrm{NaCl} / 1)$ at $35^{\circ} \mathrm{C}$ within $2 \mathrm{~h}$. To obtain oocytes only during the follicular phase of the cycle, we used gilt ovaries which did not contain a corpus luteum or corpus albicans and sow ovaries which had no corpus luteum or preovulatory large follicles. The oocytes with compact cumulus cells were washed twice with a modified KRB solution (Toyoda \& Chang, 1974) containing $1 \mathrm{mg}$ crystalline bovine serum albumin (BSA)/ml and cultured for $28-29 \mathrm{~h}$ in $0.4 \mathrm{ml}$ modified KRB solution ( $4 \mathrm{mg} \mathrm{BSA} / \mathrm{ml})$ in a plastic dish $(55 \times 15 \mathrm{~mm}$ ) covered with paraffin oil under atmosphere of $5 \% \mathrm{CO}_{2}$ in air at $37^{\circ} \mathrm{C}$. Since we have previously reported that germinal vesicle breakdown occurred in $88.2 \%(67 / 76)$ of pig oocytes collected from $2-5 \mathrm{~mm}$ follicles and cultured in a modified KRB solution for $27-30 \mathrm{~h}$, reaching to the stages from metaphase-I to -II (Sato, Iritani \& 
Nishikawa, 1978), we did not examine the maturational stage of oocytes at insemination, i.e. 28-29 $h$ after culture, in this study.

\section{Preincubation of spermatozoa}

Boar epididymides were removed at the slaughterhouse and returned to the laboratory at ambient temperature within about $3 \mathrm{~h}$ after slaughter and epididymal spermatozoa were extruded from the distal portion of the cauda epididymidis by air pressure from a syringe. After being kept for 2 or $26 \mathrm{~h}$ at room temperature, $0.5 \mathrm{ml}$ semen was suspended in $4.5 \mathrm{ml}$ modified KRB solution and then washed twice by centrifugation for $10 \mathrm{~min}$ at $400 \mathrm{~g}$ to remove epididymal plasma, because a decapacitation effect of epididymal plasma on boar epididymal spermatozoa has been reported (Hunter, Holtz \& Herrmann, 1978). Sperm-rich portions of the ejaculated spermatozoa were collected from a Landrace boar by the glove method and filtered through double gauze to remove the gel particles. About $5 \mathrm{ml}$ semen were washed three times by centrifugation for $10 \mathrm{~min}$ at $400 \mathrm{~g}$ to remove seminal plasma. The washed epididymal and ejaculated spermatozoa were then resuspended in a modified $\mathrm{KRB}$ solution $(1 \mathrm{mg} \mathrm{BSA} / \mathrm{ml})$ to give concentrations of $0 \cdot 8,2,4,8$ and 16 $\times 10^{8} \mathrm{cells} / \mathrm{ml}$. Each of the sperm suspensions $(0.5 \mathrm{ml})$ was incubated for $4 \mathrm{~h}$ under the same condition as described for cultivation of oocytes. After preincubation, a portion of each sperm suspension was diluted to approximately $4 \times 10^{6} \mathrm{cells} / \mathrm{ml}$ in $0.4 \mathrm{ml}$ modified KRB solution, covered with paraffin oil, and the percentages of motile spermatozoa and the pattern of the movement were examined under an inverted phase-contrast microscope equipped with a chamber maintained at $37^{\circ} \mathrm{C}$ and the percentages of the spermatozoa with whiplash motility were recorded.

To examine the effect of exposure of epididymal spermatozoa to seminal plasma, $0.5 \mathrm{ml}$ epididymal semen was diluted in $9.5 \mathrm{ml}$ seminal plasma (sperm-rich fraction of the ejaculated semen was centrifuged at $1500 \mathrm{~g}$ for $30 \mathrm{~min}$ and the supernatant was centrifuged at $6300 \mathrm{~g}$ for 45 $\mathrm{min}$ ) and kept at $37^{\circ} \mathrm{C}$ for $10 \mathrm{~min}$. Then the spermatozoa were washed three times by centrifugation at $400 \mathrm{~g}$ for $10 \mathrm{~min}$ to remove the seminal plasma. The washed spermatozoa were then resuspended in a modified KRB solution with $1 \mathrm{mg} \mathrm{BSA} / \mathrm{ml}$ and $0.5 \mathrm{ml}$ of the sperm suspension $\left(4 \times 10^{8}\right.$ cells $/ \mathrm{ml}$ ) was incubated for $4 \mathrm{~h}$ as described above.

\section{Fertilization in vitro and examination of oocytes}

The oocytes cultured for $28-29 \mathrm{~h}$ were transferred to fresh $0.4 \mathrm{ml}$ modified KRB solution (4 mg BSA $/ \mathrm{ml}$ ); in one experiment, eggs had been freed from cumulus cells by pipetting and washed three times before insemination. A portion of the preincubated sperm suspension was introduced into the medium so that the final concentration at insemination was $2 \times 10^{6}$ cells $/ \mathrm{ml}$. After incubation for $20 \mathrm{~h}$ with spermatozoa, oocytes were fixed for 4-5 days in $25 \%$ acetic alcohol at room temperature, stained with $1 \%$ aceto-orcein and examined under a phase-contrast microscope. Oocytes having enlarged sperm head(s) or male pronucleus(ei) with the corresponding sperm tail(s) in the vitellus were considered to be penetrated. The stage of maturation of oocytes was also recorded.

\section{Results}

As shown in Table 1, when epididymal spermatozoa were preincubated at a low concentration $(0 \cdot 8$ $\left.\times 10^{8} \mathrm{cells} / \mathrm{ml}\right)$, the penetration rate was low $(11 \%)$. But when the sperm concentration at preincubation was elevated, the penetration rates increased to $71-75 \%$ at $4-16 \times 10^{8} \mathrm{cells} / \mathrm{ml}$. A high proportion $(84 \%)$ of cumulus-free oocytes was also penetrated by epididymal spermatozoa preincubated at $4 \times 10^{8} \mathrm{cells} / \mathrm{ml}$. Of 445 oocytes penetrated, $223(50 \%)$ had at least one male and one female pronucleus with penetrated sperm tail(s) (P1. 1, Figs $1 \& 2$ ). In the rest of the penetrated oocytes $(50 \%)$, various stages of enlargement of the sperm head(s) were observed in the vitellus and female chromatin was arrested at metaphase-I, metaphase-II or the meiotic division completed (Pl. 1, Fig. 3). The percentage of polyspermic oocytes was generally high (24-91\%) and increased as 

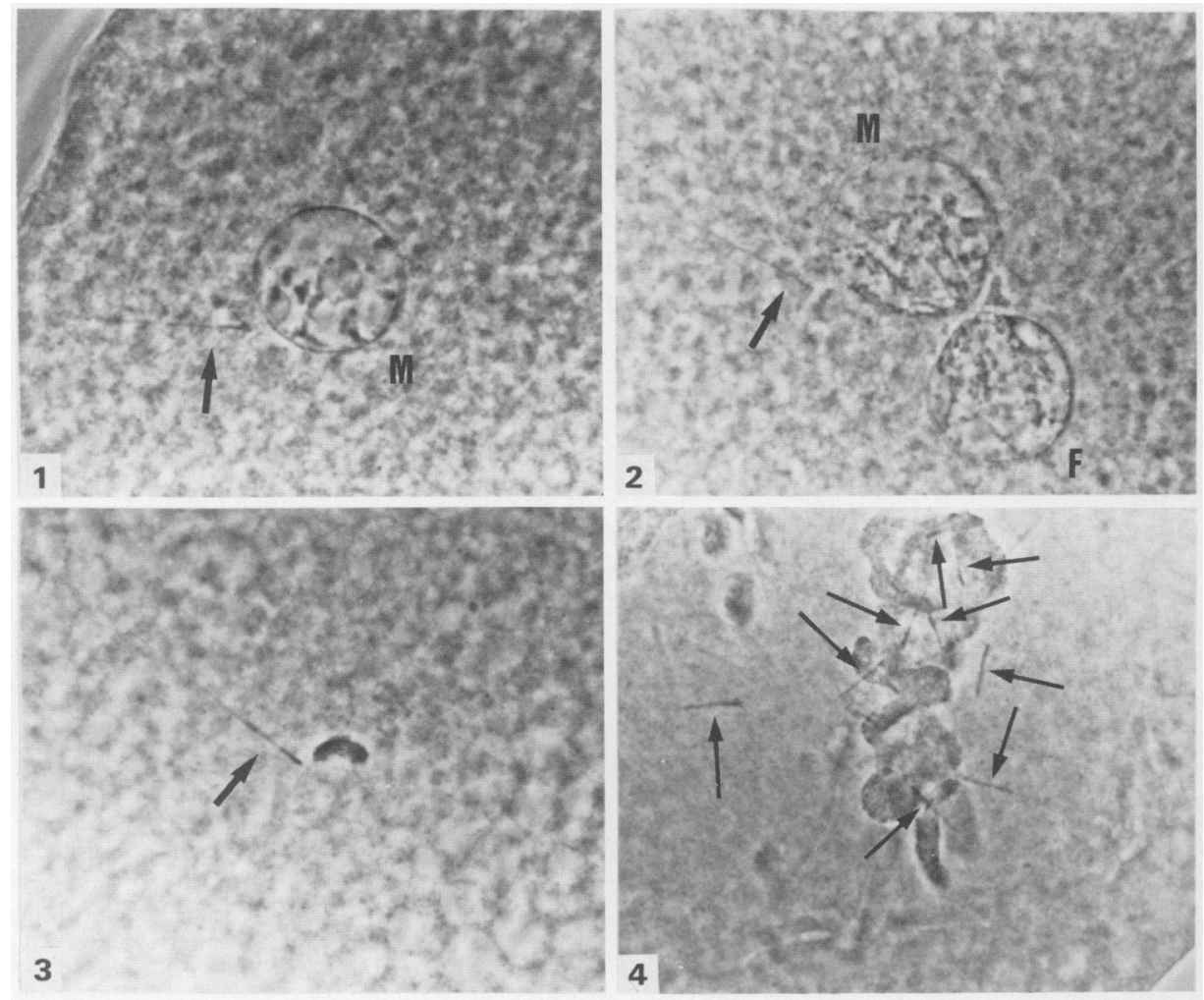

Fig. 1. Pig oocyte fixed $20 \mathrm{~h}$ after insemination with epididymal spermatozoa preincubated at a concentration of $4 \times 10^{8}$ cells $/ \mathrm{ml}$. A male (M) pronucleus and detached sperm tail (arrow) are seen. The female pronucleus and 1 st and 2 nd polar bodies are out of focus. $\times 430$.

Fig. 2. Pronuclear oocyte fixed $20 \mathrm{~h}$ after insemination with epididymal spermatozoa preincubated at a concentration of $4 \times 10^{8}$ cells $/ \mathrm{ml}$. Female $(\mathrm{F})$ and male $(\mathrm{M})$ pronuclei and detached sperm tail (arrow) can be seen. First and 2 nd polar bodies are out of focus. $\times 430$.

Fig. 3. Pig oocyte fixed $20 \mathrm{~h}$ after insemination with epididymal spermatozoa preincubated at a concentration of $8 \times 10^{8} \mathrm{cells} / \mathrm{ml}$. Swollen sperm head and detached sperm tail (arrow) are seen. Female chromatin remains at the metaphase of the second meiotic division. $\times 570$.

Fig. 4. Polyspermic oocyte fixed $20 \mathrm{~h}$ after insemination with epididymal spermatozoa preincubated at a concentration of $16 \times 10^{8}$ cells $/ \mathrm{ml}$. Enlarged sperm heads and at least 9 tails (arrow) are seen. The female chromatin at the metaphase of the second meiotic division and a 1 st polar body are out of focus. $\times 430$. 
Table 1. Effect of concentration of boar epididymal spermatozoa during $4 \mathrm{~h}$ preincubation in a defined medium on fertilization in vitro of pig follicular oocytes cultured for $28-29 \mathrm{~h}$

\begin{tabular}{|c|c|c|c|c|c|c|c|}
\hline \multirow{2}{*}{$\begin{array}{l}\text { Sperm conc. } \\
\text { during } \\
\text { preincubation } \\
\left(\times 10^{8} / \mathrm{ml}\right)\end{array}$} & \multirow[b]{2}{*}{$\begin{array}{l}\text { No. of } \\
\text { trials }\end{array}$} & \multirow{2}{*}{$\begin{array}{c}\text { No. of } \\
\text { oocytes } \\
\text { inseminated }\end{array}$} & \multicolumn{3}{|c|}{ No. of oocytes penetrated* } & \multirow{2}{*}{$\begin{array}{c}\text { No. of } \\
\text { polyspermic } \\
\text { oocytes }(\%) \dagger\end{array}$} & \multirow{2}{*}{$\begin{array}{c}\text { Mean no. } \\
\text { of sperm./ } \\
\text { oocyte }\end{array}$} \\
\hline & & & $\begin{array}{l}\text { Total } \\
(\%)\end{array}$ & $\begin{array}{l}\text { With enlarged } \\
\text { sperm head(s) }\end{array}$ & $\begin{array}{c}\text { With both } \\
\text { pronuclei }(\%) \dagger\end{array}$ & & \\
\hline 0.8 & 9 & 152 & $17(11)$ & 13 & $4(24)$ & $4(24)$ & $1 \cdot 4$ \\
\hline 2 & 7 & 104 & $51(49)$ & 18 & $33(65)$ & $41(80)$ & $6 \cdot 1$ \\
\hline 4 & $\begin{array}{l}13 \\
2 \ddagger\end{array}$ & $\begin{array}{r}222 \\
57\end{array}$ & $\begin{array}{r}157(71) \\
48(84)\end{array}$ & $\begin{array}{l}80 \\
18\end{array}$ & $\begin{array}{l}77(49) \\
30(63)\end{array}$ & $\begin{array}{l}99(63) \\
45(94)\end{array}$ & $\begin{array}{l}4 \cdot 6 \\
5 \cdot 7\end{array}$ \\
\hline 8 & 7 & 129 & $97(75)$ & 42 & $55(57)$ & $79(81)$ & $8 \cdot 3$ \\
\hline 16 & 5 & 101 & $75(74)$ & 51 & $24(32)$ & $68(91)$ & $11 \cdot 7$ \\
\hline
\end{tabular}

* The oocytes were examined $20 \mathrm{~h}$ after insemination.

$\dagger$ Percentage of oocytes penetrated.

$\ddagger$ Oocytes were freed from cumulus cells before insemination.

the penetration rates increased. The number of spermatozoa penetrating an oocyte ranged from 1.4 to 11.7 (P1. 1, Fig. 4). The chromatin aggregation was similar to that described by Hunter (1976) for polyspermic eggs.

As shown in Table 2, none of the oocytes inseminated with ejaculated spermatozoa that were preincubated at concentrations of $0.8,4$ or $16 \times 10^{8} \mathrm{cells} / \mathrm{ml}$ were penetrated. No penetration was observed when epididymal spermatozoa were exposed once to the seminal plasma before preincubation.

The percentage of motile spermatozoa after preincubation was $60-80 \%$ in all cases (Table 3). Whiplash motility (hyperactivation) was observed only in the epididymal spermatozoa. The

Table 2. Experiment on sperm penetration in vitro using ejaculated spermatozoa or epididymal spermatozoa exposed to seminal plasma

\begin{tabular}{lcccc}
\hline $\begin{array}{c}\text { Source } \\
\text { of }\end{array}$ & $\begin{array}{c}\text { Sperm conc. } \\
\text { during pre-incubation } \\
\left(\times 10^{8} / \mathrm{ml}\right)\end{array}$ & $\begin{array}{c}\text { No. of } \\
\text { trials }\end{array}$ & $\begin{array}{c}\text { No. of } \\
\text { oocytes } \\
\text { inseminated }\end{array}$ & $\begin{array}{c}\text { No. of } \\
\text { oocytes } \\
\text { penetrated }\end{array}$ \\
\hline Ejaculated & $0 \cdot 8$ & 6 & 98 & 0 \\
Epididymal & 4 & 6 & 109 & 0 \\
\hline
\end{tabular}

* Spermatozoa were exposed once to seminal plasma before preincubation.

Table 3. Effect of concentration of boar spermatozoa during preincubation for $4 \mathrm{~h}$ on their motility and movement pattern

\begin{tabular}{cccc}
\hline $\begin{array}{c}\text { Source of } \\
\text { spermatozoa }\end{array}$ & $\begin{array}{c}\text { Sperm conc. } \\
\text { at preincubation } \\
\left(\times 10^{8} / \mathrm{ml}\right)\end{array}$ & $\begin{array}{c}\text { Motile } \\
\text { spermatozoa } \\
(\%)\end{array}$ & $\begin{array}{c}\text { Spermatozoa with whiplash } \\
\text { motility/motile spermatozoa } \\
(\%)\end{array}$ \\
\hline Epididymal & $0 \cdot 8$ & $60-70$ & $0-20$ \\
& 2 & $70-80$ & $10-50$ \\
& 4 & $70-80$ & $10-70$ \\
Ejaculated & 8 & $70-80$ & $50-80$ \\
& 16 & $70-80$ & $40-90$ \\
& $0 \cdot 8$ & $60-70$ & 0 \\
& 4 & 70 & 0 \\
\hline
\end{tabular}


proportion of spermatozoa with such movement increased as the sperm concentration during preincubation increased.

\section{Discussion}

Pavlok (1981) reported that all the zona-free oocytes collected from preovulatory follicles of gilts treated with PMSG and hCG were penetrated by ejaculated boar spermatozoa preincubated for $4 \mathrm{~h}$ at a high concentration $\left(7-9 \times 10^{8}\right.$ cells $\left./ \mathrm{ml}\right)$. The present results indicate that preincubation of epididymal spermatozoa for $4 \mathrm{~h}$ at a high concentration is also effective for capacitation of spermatozoa followed by a high penetration rate of zona-intact oocytes. Since, in our previous study, epididymal spermatozoa were preincubated at $0.8 \times 10^{8}$ cells $/ \mathrm{ml}$ and only 1 of 30 cultured oocytes was penetrated, the remarkable improvement in the penetration rate obtained in the present experiment could be due to increased concentration of spermatozoa during preincubation. The mechanism is not clear, but boar spermatozoa contain taurine and hypotaurine (van der Horst \& Grooten, 1966), which stimulate capacitation of hamster spermatozoa (Meizel, Lui, Working \& Mrsny, 1980). In the present experiment, therefore, a considerable amount of these $\beta$-amino acids might be released from the concentrated spermatozoa (dead and/or alive). Although Pavlok (1981) suggested that high concentrations of calcium lactate $(2.92 \mathrm{mM})$ and calf serum proteins $(20 \mathrm{mg} / \mathrm{ml})$ in the medium are also the main factors for successful penetration of zona-free eggs, we used standard concentrations of calcium lactate $(1.72 \mathrm{mM})$ and BSA $(1-4 \mathrm{mg} / \mathrm{ml})$ in the medium.

In contrast to epididymal spermatozoa, no ejaculated spermatozoa penetrated oocytes even when they were pretreated under the similar conditions (Table 2). Furthermore, exposure of epididymal spermatozoa to seminal plasma before preincubation made them incapable of penetrating oocytes. These results support the suggestion that seminal plasma contains spermcoating antigenic components which tightly cover the sperm surface and cannot be readily removed (Oliphant \& Brackett, 1973). These sperm-coating components covering epididymal spermatozoa during incubation for $10 \mathrm{~min}$ at $37^{\circ} \mathrm{C} \mathrm{might} \mathrm{not} \mathrm{have} \mathrm{been} \mathrm{removed} \mathrm{by} \mathrm{centrifugation} \mathrm{for} 10 \mathrm{~min}$ at $400 \mathrm{~g}$, preincubation for $4 \mathrm{~h}$ and additional culture with oocytes for $20 \mathrm{~h}$. Ejaculated spermatozoa, although exposed to the seminal plasma components, might be partly capacitated during preincubation at a high concentration, because they are able to penetrate zona-free pig eggs (Pavlok, 1981). Pavlok (1981) stated, however, as unpublished experiments, that the fertilization of zona-intact pig eggs by the method used for zona-free eggs was unsuccessful. Therefore, full capacitation of ejaculated spermatozoa might not be achieved by preincubation at a high concentration, resulting in an inability to penetrate the zona pellucida.

Since a very high proportion $(84 \%)$ of the denuded oocytes were penetrated by epididymal spermatozoa, it is suggested that follicular cells do not have a role for inducing capacitation of boar epididymal spermatozoa in the present experimental condition. This clearly demonstrates that boar epididymal spermatozoa are capacitated during incubation in a chemically defined medium.

Fulka, Pavlok \& Fulka (1982) reported that pronuclear formation was arrested in about half of the penetrated oocytes (zona-free bovine follicular oocytes matured in culture) and suggested an importance of cytoplasmic maturation of oocytes in culture, i.e. synthesis of "male pronucleus growth factor". In the present experiment, we also used cultured oocytes from the germinal vesicle stage. Consequently, the arrested male pronuclear formation in about half of the penetrated oocytes may be due to the incomplete cytoplasmic maturation of the oocytes.

In vivo the sperm head swells $1 \mathrm{~h}$ after penetration and is transformed to a pronucleus $6-8 \mathrm{~h}$ later with first cleavage of pig eggs occurring 12-14 $\mathrm{h}$ after the estimated time of sperm penetration (Hunter, 1972). In the present study, since the sperm head remained enlarged or at the pronucleus stage in all the oocytes penetrated, $20 \mathrm{~h}$ after insemination, it seems that cytoplasmic maturation of the oocytes was not completed at insemination, resulting in arrested development as suggested by Polge \& Dziuk (1965) or that capacitation was not fully induced during preincubation for $4 \mathrm{~h}$ and resulted in delayed penetration. 
Yanagimachi (1969) observed a vigorous whiplashlike beating of flagellum shortly before the acrosome reaction of hamster spermatozoa and called it 'hyperactivation' (Yanagimachi, 1981). This type of movement has been reported as an essential prerequisite for fertilization in vitro for the guinea-pig (Barros, Berríos \& Herrera, 1973), dog (Mahi \& Yanagimachi, 1976) and mouse (Fraser, 1977). The same type of sperm movement observed in the present experiment (Table 3) seems to be correlated with penetration rates (Table 1). It is likely that only capacitated spermatozoa display hyperactivated movement in the pig.

Our system of using zona-intact pig oocytes will provide a useful means of understanding the mechanism of capacitation and fertilization in this species.

\section{References}

Barros, C., Berríos, M. \& Herrera, E. (1973) Capacitation in vitro of guinea-pig spermatozoa in a saline solution. J. Reprod. Fert. 34, 547-549.

Fraser, L.R. (1977) Motility patterns in mouse spermatozoa before and after capacitation. J. exp. Zool. 202 , 439-444.

Fulka, J., Jr, Pavlok, A. \& Fulka, J. (1982) In-vitro fertilization of zona-free bovine oocytes matured in culture. J. Reprod. Fert. 64, 495-499.

Hunter, R.H.F. (1972) Fertilization in the pig: sequence of nuclear and cytoplasmic events. J. Reprod. Fert. 29, 395-406.

Hunter, R.H.F. (1976) Sperm-egg interactions in the pig: monospermy, extensive polyspermy, and the formation of chromatin aggregates. J. Anat. 122, 43-59.

Hunter, R.H.F., Holtz, W. \& Herrmann, H. (1978) Stabilizing role of epididymal plasma in relation to the capacitation time of boar spermatozoa. Anim. Reprod. Sci. 1, 161-166.

Iritani, A., Niwa, K. \& Imai, H. (1978) Sperm penetration of pig follicular oocytes matured in culture. J. Reprod. Fert. 54, 379-383.

Mahi, C.A. \& Yanagimachi, R. (1976) Maturation and penetration of canine ovarian oocytes in vitro. J. exp. Zool. 196, 189-196.

Meizel, S., Lui, C.W., Working, P.K. \& Mrsny, R.J. (1980) Taurine and hypotaurine: their effects on motility, capacitation and the acrosome reaction of hamster sperm in vitro and their presence in sperm and reproductive tract fluids of several mammals. Develop. Growth Different. 22, 483-494.

Nagai, T., Niwa, K., Iritani, A. \& Leidl, W. (1983)
Improved rates of sperm penetration in vitro of pig follicular oocytes matured in culture. Jap. J. Fert. Steril. 28, 313-318.

Oliphant, G. \& Brackett, B.G. (1973) Immunological assessment of surface changes of rabbit sperm undergoing capacitation. Biol. Reprod. 9, $404-414$.

Pavlok, A. (1981) Penetration of hamster and pig zonafree eggs by ejaculated spermatozoa preincubated in vitro. Int. J. Fertil. 26, 101-106.

Polge, C. \& Dziuk, P. (1965) Recovery of immature eggs penetrated by spermatozoa following induced ovulation in the pig. J. Reprod. Fert. 9, 357-358.

Sato, E., Iritani, A. \& Nishilkawa, Y. (1978) Rate of maturation division of pig follicular oocytes cultured in vitro. Jap. J. zootech. Sci. 49, 400-405.

Toyoda, Y. \& Chang, M.C. (1974) Fertilization of rat eggs in vitro by epididymal spermatozoa and the development of eggs following transfer. J. Reprod. Fert. 36, 9-22.

van der Horst, C.J.G. \& Grooten, H.J.G. (1966) The occurrence of hypotaurine and other sulf-containing amino acids in seminal plasma and spermatozoa of boar, bull and dog. Biochem. Biophys. Acta 117, 495497.

Yanagimachi, R. (1969) In vitro acrosome reaction and capacitation of golden hamster spermatozoa by bovine follicular fluid and its fractions. J. exp. Zool. 170, 269-280.

Yanagimachi, R. (1981) Mechanism of fertilization in mammals. In Fertilization and Embryonic Development In Vitro, pp. 81-182. Eds L. Mastroianni, Jr \& J. D. Biggers. Plenum Press, New York.

Received 7 June 1983 